\title{
INSTITUTIONALIZED PUBLISHING PRACTICES AS A BARRIER TO PARTICIPATION IN THE GLOBAL MANAGEMENT DISCOURSE
}

\author{
Przemysław G. Hensel* ${ }^{\circledR}$ http://orcid.org/0000-0002-2352-2317
}

\begin{abstract}
Background. Eastern European authors in general, and Polish authors in particular hardly ever publish their work in the top management journals. For instance, out of the 3710 Administrative Science Quarterly papers available in the Web of Science, only $6(0.16 \%)$ were authored or co-authored by scholars residing in the Eastern Europe, including none residing in Poland. The situation is not much better when we take a look at European management journals: Organization Studies features only 24 papers $(0.87 \%$ of all OS papers available in WoS) authored by scholars residing in Eastern Europe, while Journal of Management Studies so far published one such paper $(0.03 \%$ of all).

Research aims. The study aims at answering the question by analyzing institutionalized publishing practices manifested in the submission guidelines of Polish and global management journals.

Methodology. Content analysis of submission guidelines in two samples of journals: global and Polish.

Key findings. The study identified significant differences between Polish and global institutionalized publishing practices, regarding the requirements toward the contribution, the role of reviewers, and the technical features of papers. The obtained results shed light on difficulties associated with publishing papers by Polish scholars in the global top management journals. Findings also suggest that adopting different institutionalized practices necessary for successful submissions to global journals may be associated with identity work and depends on author's willingness and ability to engage in such work. Finally, the results of this study contribute to research on the Americanization of management education and on the persistence of institutionalized practices despite prolonged exposure to global literature on management.
\end{abstract}

Keywords: institutional theory, practices, publishing, management journals, Americanization.

JEL Codes: M10, M14

Faculty of Management, University of Warsaw, Szturmowa 1/3, Warsaw 02-678, Poland.

E-mail: phensel@uw.edu.pl 


\section{INTRODUCTION}

While initially theory of organization was developed mainly in the US (Grey, 2010; March, 2005, 2007; Podsakoff et al., 2008), articles authored by scholars from other parts of the world are recently increasingly common in the top management journals (Mangematin \& Baden-Fuller, 2008; Saunders et al., 2011). Unfortunately, scholars from the Eastern Europe in general, and Poland, in particular, seem to be significantly underrepresented in the global exchange of ideas about organizations as documented by the fact that studies conducted by researchers from that region are hard to come by in the pages of top management journals. For instance, out of the 3710 Administrative Science Quarterly papers available in the Web of Science, only $6(0.16 \%)$ were authored or co-authored by scholars residing in the Eastern Europe, including none residing in Poland. Even the top European management journal - Organization Studies - features only 24 papers $(0.87 \%$ of all OS papers available in WoS) authored by scholars residing in the Eastern Europe, with 10 paper written by Poles. Journal of Management Studies so far published one paper authored by an Eastern European author. Why?

Multiple reasons have been suggested as responsible for this state of affairs such as underfunding and excessive teaching loads (Dobija \& Hałas-Dej, 2017; Obłój, 2008), deficiencies of the peer review system (Jia et al., 2012; Tsui, 2013) associated with parochialism of management science community (March, 2005, 2007), and communication barrier (Horn, 2017; Śliwa \& Johansson, 2014, 2015) associated with the need to author papers in English. In this article, I contribute to the understanding of this problem by advancing another explanation that points to a less obvious but potentially equally important factor. I claim that the underrepresentation of Polish scholars in the global discourse is to some degree caused by a difference between global and local (Polish) institutionalized publishing practices. Institutions do not only guide behavior but also shape cognition: institutionalized practices are taken for granted, seen as normal and obvious (Scott, 2008; Tolbert \& Zucker, 1996). Thus, the received vision of the proper publishing practices typical for a given community of scholars may constitute a major barrier to writing articles likely to be accepted by the top management journals if such vision is inconsistent with the 
practices institutionalized in the global community. Empirical studies of such discrepancies related to the authoring of scholarly papers are so far nonexistent thus a significant gap in our knowledge does exist.

Addressing that gap by discovering institutionalized barriers to participation in the global scholarly community seems to be important for a number of reasons. First, it may have liberating qualities: reconsidering institutionalized publishing practices may permit to adjust them, thus allowing Eastern European scholars to participate in the global ideas market fully. Second, increased participation of Eastern European scholars in that market may bring new ideas and points of view to the debate thus enriching the global discourse on organizations. Third, given the recent increase in interest in replication research (Bettis et al., 2016; Gelman, 2015; Gelman \& Loken, 2014; Hensel, 2019), testing extant theories with Eastern European samples may help identify theories' boundaries and limitations. Fourth, the findings of this study may constitute a departure point for similar studies in other underrepresented regions, such as South America, Africa, and parts of Asia. These reasons suggest that studying causes for the insufficient number of Polish papers appearing on the pages of global management journals is warranted.

While it is relatively easy to study the shape and content of published papers, exploring practices that led to the publication of such papers seems to be inherently more difficult for it requires to observe what scholars, editors, and reviewers do, when they make authorial and editorial decisions. One solution to this problem can be found in studying submission guidelines formulated by the journals' editors. Such guidelines can be seen as the outcome of institutional sedimentation (Tolbert \& Zucker, 1996). Practices repeated over the years are written down in order to signal expectations of the editors to the prospective authors. Such expectations are likely extensively shaped by the beliefs and practices shared by a given community of scholars. Thus, studying submission guidelines can be helpful in discovering an institutionalized vision of the publishing and writing practices shared by a particular community.

Drawing on a comparison of submission guidelines of five top global and five top Polish management journals I identify inconsistencies in requirements related to the content, the submission process, the review process, and the technical aspects of formatting the paper. In the "Discussion", I use these findings to shed light on a number of issues. First, 
I show how the Polish institutionalized practices are more similar to a vision of an ideal paper common in natural sciences rather than in the management science, thus making it difficult for the Polish scholars to submit papers to global journals successfully. Second, I highlight how working from the periphery and adopting the global publishing requirements while rejecting or reevaluating the local ones may require involvement in identity work. Finally, finding of this study contribute to extant research on Americanization of management education, by showing how Americanization of the Polish business school has been only partial and not followed by the adoption of global, that is largely American, institutionalized publishing practices.

\section{BACKGROUND}

Despite the high level of Americanization of the Eastern European and Polish management education (Koźminski, 2008; Kwiatkowski \& Koźmiński, 1992) the participation of Polish scholars in the global discourse seems to be insufficient. For instance, in a recent study of scholarly impact in management science not a single university from the Eastern Europe in general, and from Poland in particular has been found to have any impact on the development of the discipline, while universities from far less populous countries such as the Netherlands, Singapore, Israel, and Sweden are featured on that list (Podsakoff et al., 2008). In a similar vein, the study of a premier European outlet Organization Studies - shows that Eastern Europe plays almost no role in the development of the discipline. Countries belonging to the so-called "periphery", that is Portugal, Spain, Italy, Greece, Turkey, Cyprus, Poland, and the former Yugoslavia, account for mere 9.5\% of all papers published in that journal by the European scholars (Üsdiken, 2010, p. 726).

Multiple reasons offered as an explanation of this phenomenon are reviewed below to set the stage for the findings section.

\section{Limited resources}

One explanation for the low presence of the Polish authors in the global management discourse can be sought for in the limited resources available to Eastern European scholars. Government spending on research 
and development in Poland and the other Eastern European countries is on average lower than in the Western part of Europe, both in absolute and percent of GDP terms (Eurostat, 2016). The teaching loads in that part of the world are usually rather heavy (Dobija \& Hałas-Dej, 2017; Obłój, 2008), especially if compared to most prestigious US and European universities. Insufficient financial resources available to authors and time-consuming teaching assignments likely impact both the quantity and quality of research conducted within this part of Europe. This issue of resources also manifests when scholars are required to secure open access to their articles since fees demanded by top publishers are exorbitant for Eastern European scholars and their host institutions. In other words, low participation in the global exchange of ideas can be at least partially explained by a low supply of research provided by the Polish authors due to limited access to resources.

\section{Peer review bias and parochialism of management science}

Recent research shows quite convincingly that the peer review system used for evaluation of scholarly contributions is not without prejudices and deficiencies (Baxt et al., 1998; Hensel, 2017; Schroter et al., 2008). Most markedly, the outcome of the review is sometimes conditioned by factors extending beyond the quality of the submission.

First, the prestige of an institution to which an author is affiliated may impact the result of the review. According to Ceci and Peters (1982), work submitted by scholars affiliated with more prominent universities may be reviewed more positively than studies by scholars from obscure educational entities. Given the low presence of Polish schools in the global first league of universities documented in rankings such as Times Higher Education World University Rankings 2016-2017 and Academic Ranking of World Universities 2014, this factor may contribute to low chances of papers from Poland being published in the top journals. While the peer review is blind in theory, the advent of the Internet means that hiding the identity of a scholar is increasingly difficult (Hillman \& Rynes, 2007). Also, while reviewers do not know the identity of the author, the editors are fully aware of it. Thus, the peer review bias remains as one of the explanations of the problem.

Second, the positive outcome of a review depends on the level of intellectual congruence between the author and the reviewers. This 
issue seems to be particularly significant since the community of management science is characterized by parochialism (March, 2005) and the existence of invisible colleges of authors (Vogel, 2012) that share distinct interests and assumptions about reality, methods, and goals of science (Boyacigiller \& Adler, 1991). When authors' and reviewers' assumptions, writing and cognitive styles are incongruent the risk of rejection increases (Bedeian, 2004). As a consequence authors publishing in a given journal usually are very similar regarding place of education and affiliation to the editors of the journal (Bedeian, 2004). Scholars from Poland, infrequently being involved with global colleges are likely to face challenges resulting from such incongruence. Their style of argumentation or application of methods acquired in Eastern European educational facilities can be seen as improper because of their inconsistency with standards shared by scholars trained at the top American and European institutions.

Third, research that involves Eastern European organizations and settings may appear as irrelevant to Western reviewers (Jia et al., 2012; Tsui, 2013), thus being evaluated as less important or of lower quality than contributions from the West.

\section{Communication barrier}

Another obstacle that the Polish authors need to cross relates to the dominance of English language in scholarly communication. Authoring a paper while not being a native speaker constitutes a challenge that may manifest itself in at least two ways. First, it is possible that manuscripts that deviate from "perfect", eloquent use of that language are viewed as inferior, thus the chances of rejection are increased (Horn, 2017). Importantly, the fluent use of academic English extends beyond knowledge of correct grammar and vocabulary and involves use of right conventions, such as hedging, that is use of terms that allow making claims less assertive (e.g. "it suggests" rather than "it proves") (Habib Bajwa et al., 2016). Secondly, the awareness of the non-native speaker status may undermine scholar's confidence in his or her ability to meet the expectations of top journals' reviewers (Horn, 2017; Śliwa \& Johansson, 2014, 2015) resulting in the abandonment of such attempts thus contributing to decrease in the supply of research from Poland. 


\section{Institutionalized practices}

Finally, some preliminary evidence suggests that non-American authors have to face challenges resulting from lack of knowledge of institutionalized practices followed by authors affiliated with American institutions. Even though research on such challenges is scarce, some cues can be gleaned from the editorial entitled "Publishing in AMJ for non-U.S. Authors" that recently appeared on the pages of the Academy of Management Journal (George, 2012). According to its author, the common mistakes made by foreign scholars include: focusing on data from the particular country while failing to provide new theoretical contribution; providing underdeveloped theory section based on an overview of literature rather than on finding and formulating causal relationships; and improper research design that does not fit the research question. Finally, the non-American authors may not be aware of the "house style" (George, 2012, p. 1025) that defines how the argument should be made and presented. This category involves a range of issues, such as meta-structure of the argument (explanation centered on theory vs. on the studied phenomenon), formatting of references, presentation of tables and figures, and description of sections of the manuscript. Following such institutionalized norms is crucial for the successful submission. To quote from the aforementioned editorial:

Not adhering to the formatting requirements indicates that a submission is likely from a novice or a non-Academy member; in either case, it doesn't help the submitting author in terms of reviewer confidence that the author has the capability or skill to successfully revise the manuscript for eventual acceptance (George, 2012, p. 1025).

Departing from this vantage point, I proceed to compare submission guidelines of top global and Polish management journals in order to identify similarities and differences related to institutionalized publishing practices encapsulated in such guidelines. 


\section{METHOD}

\section{Sample - journal selection}

The assumption behind this study maintains that institutionalized publishing practices can be discovered by exploring submission guidelines formulated by editors of management journals published by the global and Polish research communities. However, not all journals are equally fitted for such analysis as they vary both in their reach and quality. Thus I focus on so-called top journals for both studied communities, assuming that their position reflects their commitment to values held high in each community and congruence with institutionalized expectations. At the same time these journals can be seen as elite organizations setting the standards for the entire community (Greenwood \& Suddaby, 2006; Simsek et al., 2013), thus allowing to generalize finding from this study onto the entire field.

\section{The global journals}

The list of five global journals selected for further analysis was built on the basis of the Thomson Reuters Web of Knowledge Journal Citation Reports edition 2016. To ensure comparability, the journals that do not publish empirical papers and those that focus on specific areas of management theory and practice were excluded from the list. Specifically, the high-ranking journals such as Academy of Management Annals, Academy of Management Review, International Journal of Management Reviews were excluded from further analysis because they do not publish empirical studies, while other high-ranking journals such as Strategic Management Journal, MIS Quarterly, Journal of Supply Chain Management were excluded because they cover specific areas of management science, thus their submission guidelines may reflect specific requirements associated with these areas. The final list of journals included: Academy of Management Journal, Journal of Management, Administrative Science Quarterly, Journal of Management Studies, Organization Science. 


\section{The Polish journals}

The lack of universally agreed impact factor indexes for Polish journals meant that the list of journals published by the Ministry of Science and Higher Education had to be consulted in search for the most impactful periodicals. The B list of journals (edition 2016) was searched for periodicals that have highest scores, and their titles contain keywords like "management" ("zarządzanie", "kierowanie"), "organization" ("organizacja"), and "administration" ("administracja") and its derivatives. The same criteria for inclusion were applied as in the global journals sample (focus on empirical research, general scope) with an additional requirement that majority of papers published in the selected journals are written in Polish. Thus, high-ranking but area-specific journals such as Culture Management (Zarzadzanie w Kulturze), Human Resource Management (Zarzadzanie Zasobami Ludzkimi) and Studies and Works of the Management and Finance Collegium (Studia i Prace Kolegium Zarzadzania i Finansów) were excluded from the further analysis. The final list included: Organization and Management (Organizacja i Kierowanie), Organization Review (Przeglad Organizacji), Economics and Organization of Enterprises (Ekonomika i Organizacja Przedsiębiorstw), Entrepreneurship and Management (Przedsiębiorczość i Zarzqdzanie), and Management Issues (Problemy Zarzadzania).

\section{Content analysis}

In the next step of the analytical procedure, a content analysis of submission guidelines was used to discover categories that were central in either or both samples. This analytic technique - increasingly common in management research (Duriau et al., 2007) - seems to be particularly well-suited for institutional analyses (Brown et al., 2012; Green et al., 2009; Suddaby \& Greenwood, 2005). The analysis was performed with the help of Atlas.ti software package. Altogether 22 sub-categories were identified which were later grouped into four main categories: "Content requirements", "Review process requirements", "Submission process requirements", and "Technical requirements". Once the sub-categories were established editorial guidelines of each of the journals were studied once again to find if they feature a given sub-category. In a subsequent step of an analytical procedure obtained 
data were entered into a table, either in a binary form (requirement present / not present) or as numbers (e.g., 180 days for resubmission of a reviewed paper). Next, for the former sums were calculated, and for the latter - the averages.

One of the categories turned out to be both central and associated with certain empirical problems. The maximum length of submitted papers is sometimes stated in pages, sometimes in words, and sometimes in the number of characters. What is more, the global journals limits are usually given by referring to double-spaced pages, while Polish editors cite 1.5-spaced pages. Most journals declare that given page limit includes all elements of the paper (that is, abstract, main text, references, footnotes, tables, and figures) but one sets a limit that encompasses the main text only. Finally, while most journals require 12 points font, one of the studied periodicals asks for submissions typed with 11-point font.

The following steps were taken to ensure compatibility of data. First, all the requirements towards length of the paper were converted to the lowest common denominator, that is the number of characters including spaces. In order to achieve that I copied texts from published papers into Word file, then adjusted the formatting according to specifications set by a given journal and calculated an average number of characters per page. Second, to address the issue of inclusive and exclusive definitions of paper length the journal that uses exclusive length limit (ASQ)* was excluded from this part of the analysis. Third, to address the fact that the same text presented in Polish and English will differ in length, I compared 20 European Union's Green Papers and White Papers that are available in both languages. This allowed establishing that the Polish-language version of a text is on average 15 to $20 \%$ longer than the English-language version.

\footnotetext{
To be precise, ASQ guidelines say that it "does not have page limits, but we favor manuscripts that offer high intellectual value per page. Because of the difficulty of finding scholars who are willing to review very long manuscripts, we suggest, as a general guideline, that authors aim for manuscripts of 45 pages or fewer of text (not including references, tables, figures, or appendices)" (ASQ, 2018).
} 


\section{RESULTS}

The content analysis of 10 journals allowed to identify four main categories of requirements: towards the content, the review process, the submission process, and the technical aspect of formatting papers. The overview of findings is summarized in table 1 . While there are some similarities between the two studied groups of journals, significant differences do exist, and they allow to shed light on the uniqueness of institutionalized publishing practices for the global and the Polish communities of scholars.

Table 1. Comparison of requirements present in the submission guidelines of the global and the Polish management journals

\begin{tabular}{|c|c|c|}
\hline Requirements stated in the submission guidelines & $\begin{array}{c}\text { Global } \\
\text { journals }\end{array}$ & $\begin{array}{c}\text { Polish } \\
\text { journals }\end{array}$ \\
\hline \multicolumn{3}{|l|}{ Content requirements } \\
\hline Empirical contribution & 3 & 0 \\
\hline Theoretical contribution & 4 & 0 \\
\hline Practical contribution & 2 & 0 \\
\hline Structure of the paper & 0 & 4 \\
\hline \multicolumn{3}{|l|}{ Review process requirements } \\
\hline Number of reviewers & 2.3 & 2 \\
\hline Time to feedback (days) & 75.0 & N/A \\
\hline Time for revision (days) & 272.5 & 14 \\
\hline \multicolumn{3}{|l|}{ Submission process requirements } \\
\hline Seeking advice from colleagues suggested & 4 & 0 \\
\hline Anonymity & 4 & 0 \\
\hline Drafts removed from the Internet & 2 & 0 \\
\hline E-mail submission allowed & 1 & 5 \\
\hline Surface mail submission allowed & 0 & 3 \\
\hline Web submission allowed & 4 & 0 \\
\hline Submission not published before & 4 & 1 \\
\hline Submission not under review & 5 & 1 \\
\hline
\end{tabular}


Table 1. cont.

\begin{tabular}{|l|c|c|}
\hline \multicolumn{1}{|c|}{ Requirements stated in the submission guidelines } & $\begin{array}{c}\text { Global } \\
\text { journals }\end{array}$ & $\begin{array}{c}\text { Polish } \\
\text { journals }\end{array}$ \\
\hline Financial disclosure & 0 & 3 \\
\hline Properly stating authorship & 1 & 5 \\
\hline Technical requirements & 4 & \multicolumn{2}{|c|}{4} \\
\hline Format of references and citations explained with examples & 5 & 175 \\
\hline Figures and tables placed at the end of the document & 200 & 25 \\
\hline Abstract length (words) & 94,890 & 43,453 \\
\hline Paper length (characters) & none & 25 \\
\hline References limit & 4 \\
\hline
\end{tabular}

Source: own analysis of journals in the global and Polish samples.

\section{Content requirements}

All of the periodicals in the global sample set requirements regarding the contribution presented in the submitted papers. Four of them require that the manuscripts contain strong theoretical contribution, that allows to extend the existing theories of management or build new ones. Three of the said periodicals also explicitly demand significant empirical contribution, that is a presentation of facts that have not been already known in the scholarly literature. Two journals also ask that the contributions are relevant to the practice of management, even if not directly.

None of the journals in the Polish sample specifies explicitly any requirements associated with the theoretical, empirical, and practical contribution of the manuscript. Instead, the editors of these journals list areas of interest that the submitted papers should cover.

The studied samples also differ in attention put on the structure of the manuscript. In the global sample, the structure is not explicitly suggested, some journals (like ASQ) openly state that they leave the freedom to shape the structure of their argument to the authors. In the Polish sample, two journals provide explicit instruction about the structure of the text, while two other provide some cues. The suggested structure encompasses introduction, review of the literature, description of methods and presentation of results that is followed by concluding remarks or summary. However, in all the guidelines provided by the 
Polish journals one element of the paper familiar to every reader of global periodicals is missing, that is the "Discussion".

\section{The review process requirements}

The only similarity between the two samples regarding the review process is the number of reviewers. In each of the studied groups, three journals cite explicitly the number of reviewers engaged in the peer review process, with 2.3 reviewers being the average number in the global sample and 2 in the Polish sample.

The remaining two categories show significant differences. Two of the global journals provide an estimated time when the authors may expect the editorial decision (75 days on average). None of the Polish journals gives such estimate.

More importantly, two periodicals in the global sample suggest the time available to authors to submit a revised paper after the editorial decision is delivered (272.5 days on average). Only one journal in the Polish sample specifies such time, and it is set at 14 days.

\section{Submission process requirements}

The requirements associated with submitting the manuscript differ significantly between the studied groups.

First, four of the studied global journals either require or suggest that the manuscript is reviewed and discussed by authors' colleagues before the submission. The editors advise that sending a manuscript that has not been read by anyone but its authors is nearly guaranteed to result in rejection. Furthermore, mistakes made at the study planning stage (design of the study, choice of sample and methods) cannot be corrected once the study is conducted, thus some editors advise that feedback from colleagues is sought for even before the study is executed. None of the journals in the Polish sample require review by colleagues before submission.

Second, the global journals seem to put greater emphasis on the anonymity of the review process. While journals in both groups declare that they use double-blind review process, four journals in the global sample and none in the Polish sample suggest that the authors should take certain steps to ensure anonymity, such as removing identity properties from the MS Word files meta-data, 
removing drafts of the paper from the Internet, avoiding references to previous work and language that may reveal author's identity, and removing acknowledgments.

Third, four journals in the global sample explicitly require that the submitted paper has not been published before and five demand that it is not under review at a different journal. Only one journal in the Polish sample formulated such requirements.

On the other hand, the issue of properly stating paper's authorship seems to be more prominent in the Polish than in the global sample. All of the Polish journals require that only the actual authors are listed, and that ghost authorship and ceremonial authorship should be avoided at any cost, adding that cases of misattributed authorship will be revealed publicly. Only one global periodical explicitly touches the issue of authorship, and one warns that all submissions are checked for plagiarism. However, two caveats have to be made. First, the requirements regarding avoiding ghost and ceremonial authorship present in the guidelines of the Polish journals are required by the Ministry of Science and Higher Education, thus it is not surprising that they can be found in each of the studied journals. Second, while the majority of the journals in the global sample do not mention the issue of authorship, it is often covered in the web submission forms that were not analyzed within the limits of this study. The same applies to the requirement of financial disclosure that is present in three of the studied Polish guidelines and none of the global ones but is commonly covered in the web submission forms.

Finally, significant differences can also be noted regarding the technical aspect of submitting papers. Four journals in the global sample require submission by web systems (Manuscript Central) while none of the journals in the Polish sample uses such a system. All journals in the Polish sample allow submission by e-mail, one also allows submission by surface mail, while in two such form of submission is obligatory.

\section{Technical requirements}

Finally, the content analysis revealed both similarities and significant differences between two studied samples regarding the requirements towards length and formatting of the manuscripts. 
One similarity pertains to the length of the abstract that is roughly the same in both groups (200 vs. 175 words on average). Also, four journals in the global sample and four journals in the Polish sample thoroughly discuss the issue of formatting citations in the text and the references list, usually by providing examples of the correct use. However, a significant peculiarity can be noted in the Polish sample. While three journals do not set any limits on the number of references, two remaining require that the references list has no more than 25 items. None of the global journals impose limits on the number of references.

Two significant differences pertain to submission of tables and figures and the maximum length of the manuscript. All journals in the global sample require that tables and figures are attached at the end of the document, and their intended position in the text is marked by placeholders such as "insert figure 1 about here". Only one journal in the Polish sample makes a similar requirement.

Most importantly, the global and the Polish sample differ considerably in the maximum allowed length of the paper. In the global sample, the average maximum length is nearly 95 thousand characters (including spaces) while in the Polish sample it is just 43 thousand characters. Assuming that one double-spaced page contains about 2150 characters, the manuscripts submitted to global journals should be about 44 pages long at maximum, while those submitted to Polish journals are expected to be no longer than 20 pages. To put it differently, papers submitted to Polish journals should be no longer than 45\% of the maximum length of those submitted to global journals. Given that the text written in Polish is usually about 15 to $20 \%$ longer than its English-language equivalent, the Polish manuscript is expected to be no longer than 37.5 to $39 \%$ of the length of the paper submitted to the global journal.

\section{DISCUSSION}

Working from the periphery may constitute an advantage (Zilber, 2015) but the negligible amount of papers from Eastern Europe appearing on the pages of the major global management journals suggest that it is more often a liability. This paper contributes to the understanding of the nature of disadvantages associated with working from 
the periphery. Specifically, drawing on a comparison of submission guidelines for top global and top Polish management journals I provide three contributions that allow extending our knowledge regarding the institutional differences between scholarly communities.

\section{Differences in institutionalized publishing practices}

The two visions of scholarly contribution discovered in the studied guidelines are distinctly different. The ideal submission to a Polish journal exhibits strong similarity to a typical paper published in the natural sciences: focus on empirical findings rather than on theory, a brief presentation of the argument, a short list of references. The global ideal seems to be focused primarily on theory development rather than on reporting findings, thus such manuscripts are expected to be significantly longer, quote previous literature extensively, and discuss the impact of the obtained results on the extant theories.

Also, the envisioned role of reviews seems to be strikingly different within two communities. Even though only three journals (two in the global sample, one in the Polish sample) signal the expected time of returning the revised manuscript the significant difference between these times ( 273 vs. 14 days) allows to say that reviews play a different role in these traditions. In the global tradition reviewers may ask to considerably adjust the manuscript, sometimes going as far as suggesting a new theoretical framing or method of data analysis, thus considerable time is needed to address such requests. In the Polish tradition, the primary role of reviewers is to accept or reject the manuscript. Authors of the accepted manuscripts usually need to address only minor technical issues mentioned by the reviewers, hence the short time allowed for delivering a revised paper. What is more, the editors of global journals suggest that successful work needs to involve extensive consultations with colleagues, while in the Polish tradition research appears to be a solitary endeavor.

The studied guidelines also suggest that the issues of impartiality and competition are differently valued in the two studied communities. Editors of the global journals ask the authors to ensure the anonymity of submission by following certain steps like anonymizing the MS Word file or removing drafts of the document from the Internet. The editors of the Polish journals do not formulate such demands, signaling a lighter emphasis on the issue (table 2). 
Table 2. The summary of findings

\begin{tabular}{|c|c|c|}
\hline Requirements & Global journals & Polish journals \\
\hline \multicolumn{3}{|c|}{ Content } \\
\hline $\begin{array}{l}\text { Nature of the } \\
\text { contribution }\end{array}$ & $\begin{array}{l}\text { Emphasis on theory } \\
\text { development }\end{array}$ & $\begin{array}{l}\text { Emphasis on reporting empirical } \\
\text { findings }\end{array}$ \\
\hline $\begin{array}{l}\text { Structure of the } \\
\text { paper }\end{array}$ & No explicit emphasis & Strong emphasis \\
\hline \multicolumn{3}{|c|}{ Review process } \\
\hline Role of the reviewer & $\begin{array}{l}\text { Reviewer as gatekeeper } \\
\text { and advisor }\end{array}$ & Reviewer as gatekeeper \\
\hline Time for revision & Long & Short \\
\hline \multicolumn{3}{|c|}{ Submission process } \\
\hline $\begin{array}{l}\text { Seeking advice from } \\
\text { colleagues before } \\
\text { submitting }\end{array}$ & Strongly suggested & Not mentioned \\
\hline $\begin{array}{l}\text { Ensuring anonymi- } \\
\text { ty of submission }\end{array}$ & Strong emphasis & No emphasis \\
\hline $\begin{array}{l}\text { Properly stating } \\
\text { authorship }\end{array}$ & No emphasis & Strong emphasis \\
\hline \multicolumn{3}{|c|}{ Technical requirements } \\
\hline Lenght of the paper & $\begin{array}{l}\text { Long } \\
(95,000 \text { characters })\end{array}$ & $\begin{array}{l}\text { Short ( } 43,000 \text { characters) } \\
\text { (Polish submission shorter than the } \\
\text { global one by } 61 \% \text { to } 62.5 \% \text {, when } \\
\text { differences between languages are } \\
\text { factored in). }\end{array}$ \\
\hline References limit & None & 25 (avg. based on two journals) \\
\hline $\begin{array}{l}\text { References } \\
\text { formatting }\end{array}$ & Same & Same \\
\hline
\end{tabular}

Source: own analysis of journals in the global and Polish sample.

\section{Working from the periphery and the identity work}

Publishing in journals, like any activity, needs training. Typically, before authors are able to publish in the top journals, they make their first steps by submitting research to less demanding outlets. However, the glaring differences between Polish and global institutionalized requirements, disallow to use Polish journals as a training ground for submitting papers to global journals. To put it simply - a well-trained Polish author, that has many successful publications behind his or her belt is unable to use that experience to successfully submit papers to global journals. His or her manuscript written and formatted according to Polish institutionalized norms is guaranteed to result in 
rejection, regardless of its scholarly value. Papers focused on empirical findings rather than on theory development are not welcomed in the major global journals, but these are the only kind of papers that Polish scholars are trained to produce. Thus, even the experienced authors face obstacles that are typical for novices.

On the face of it, it may appear that all that is required to publish in global journals is reading and duly following their guidelines such as those studied in this paper. However, this is more challenging than it seems. First, following such guidelines depends on extensive tacit knowledge. Both the editors and reviewers assume that they share with authors certain amount of common institutionalized norms. For instance, none of the studied guidelines in the global sample say that the submitted papers should entail "Discussion" section because this is obvious to all the involved parties. The intended goals and contents of "Discussion" are never described either because they are evident too. To authors trained in other academic cultures where such sections are unknown this constitutes a serious challenge as they are left to their own devices and to guessing the meaning of that section from the papers that are already published. Moreover, since institutions guide perceptions (Scott, 2008), the incongruence of the requirements identified in this paper suggests that such tacit requirements, even if noticed, can be seen as alien and questionable. To authors trained in producing papers focused on empirical findings, "Discussion" may appear as somewhat irrelevant and of mostly rhetorical value. To some, it may even appear as an attempt at overselling empirical results that are not interesting enough to stand on their own. Similarly, the requirement to vacuum-clean the literature rather than cite only the most relevant papers may appear as misguided. In other words, the institutionalized nature of the studied practices makes it difficult to adjust to requirements formulated by a different community.

Second, adjusting to global submission guidelines may require much more than unreflexively following forms and structures suggested in such recommendations. Writing papers that are publishable by the global journals does not mean that authors need only to adopt the new, i.e. global standard. They also need to reject or at least reevaluate local standards and practices they have been trained to use. This may prove difficult since practices play a significant role in constituting identities (Dutton et al., 2010; Lok, 2010), thus rejecting familiar and 
often used practices may be associated with questioning scholar's own identity. What is more, adopting the global standard as a proper one may lead a scholar to a negative reevaluation of his or her extant work that has been written according to different standards. Thus, an apparently simple issue of authoring a paper congruent with global journals' requirements may be dependent on the author's willingness and ability to question his or her identity. In general, it can be inferred, that attempts at crossing divide between different academic cultures require involvement in identity work (Alvesson \& Willmott, 2002; Brown, 2015; Sveningsson \& Alvesson, 2003).

\section{The fragmented Americanization of management education}

The findings of this study also contribute to research on the Americanization of the management education. A considerable number of studies show convincingly that business schools around the world are becoming increasingly similar to American ones. Regardless if we consider Nordic countries (Engwall, 2004), United Arab Emirates (Juusola et al., 2015), Germany (Kieser, 2004), France, Italy, Spain, Turkey (Kipping et al., 2004) and Britain (Tiratsoo, 2004) the American model of management education affected local programs, curricula, and teaching methods. This also holds for the Polish management schools that have been influenced to a considerable extent by the American model (Koźminski, 2008; Kwiatkowski \& Koźmiński, 1992). However, the discovered incongruence of the Polish and global (largely American) institutionalized publishing practices allows claiming that in Poland, similarly to aforementioned countries, the adoption of the American model has been only partial. While the curricula of the Polish management schools are to a considerable extent based on American literature and the teaching methods are often modeled on the American examples, the publishing practices remain intact despite prolonged exposure to papers authored within the American tradition. Apparently reading American journals required to educate students according to the latest American managerial fads does not need to be followed by the adoption of the American publishing format. 


\section{Limitations}

This study, as any, has certain limitations that pertain mainly to the scope of the used data. Firstly, only 5 journals for each community were examined while there are hundreds global and dozens of Polish journals that cover the area of management. While submission guidelines of the top journals are likely to reflect the institutionalized practices for each community, it is possible that certain differences within each community exist and were not discovered because of the limited number of the studied venues. Secondly, only the submission guidelines for each journal were investigated while a considerable number of requirements associated with institutionalized practices can be found in the web submission forms. However, since none of the Polish journals uses electronic submission system, such forms were not studied to ensure comparability of the empirical material.

\section{Further research}

If it is true that institutionalized authoring practices are responsible for the underrepresentation of Polish scholars in the global journals, then similar incompatibilities should be present in the submission guidelines of journals published in the other underrepresented countries. Thus the findings of this study can be seen as a starting point for similar studies conducted in other Eastern European and non-European and non-North American countries.

The findings of this study can be tested quantitatively by comparing the frequency of publications by Eastern European scholars in disciplines adjacent to management theory. For instance, journals publishing work on finance or accounting do not require theory development in every paper and often publish manuscripts that are focused on reporting empirical findings only (Hambrick, 2007). Thus the presence of Polish authors in such outlets should be more prevalent than in the management theory journals since requirements posed by such journals are more congruent with requirements posed by the Polish journals. 


\section{CONCLUSIONS}

Drawing on a comparison of global and Polish journals' submission guidelines I identified significant differences in institutionalized publishing practices regarding requirements toward the content, the review process, the submission process, and the technical aspect of formatting papers. The two studied communities maintain substantially different visions of an ideal management science paper with the Polish ideal being close to the format used in the natural sciences and focused on reporting empirical findings while the global template emphasizes theory development and lengthy discussion of previous theory and implications of the study. Findings of the study allowed to shed light on difficulties associated with publishing papers by Polish scholars in the global top management journals. They also suggest that adopting different institutionalized requirements necessary for successful submissions to global journals may be associated with identity work and depends on author's willingness and ability to engage in such work. Finally, the results of this study contribute to research on the Americanization of management education and on the persistence of institutionalized practices despite prolonged exposure to differing requirements.

\section{REFERENCES}

Alvesson, M. \& Willmott, H. (2002). Identity regulation as organizational control: Producing the appropriate individual. Journal of Management Studies, 39(5), 619-644.

ASQ (2018). Invitation to Contributors, https://www.johnson.cornell.edu/Administrative-Science-Quarterly/Invitation-to-Contributors (accessed: 1st Dec 2018).

Baxt, W.G. et al. (1998). Who reviews the reviewers? Feasibility of using a fictitious manuscript to evaluate peer reviewer performance. Annals of Emergency Medicine, 32(3), 310-317.

Bedeian, A.G. (2004). Peer review and the social construction of knowledge in the management discipline. Academy of Management Learning \& Education, $3(2), 198-216$.

Bettis, R.A. et al. (2016). Creating repeatable cumulative knowledge in strategic management. Strategic Management Journal, 37(2), 257-261. 
Boyacigiller, N.A. \& Adler, N.J. (1991). The parochial dinosaur: Organizational science in a global context. Academy of Management Review, 16(2), 262-290.

Brown, A.D. (2015). Identities and identity work in organizations. International Journal of Management Reviews, 17(1), 20.

Brown, A.D., Ainsworth, S. \& Grant, D. (2012). The rhetoric of institutional change. Organization Studies, 33(3), 297-321.

Ceci, S.J. \& Peters, D.P. (1982). Peer review: A study of reliability. Change, 14(6), 44-48.

Dobija, D. \& Hałas-Dej, S. (2017). Higher education in management: The case of Poland. In: S. Dameron \& T. Durand (eds.). The Future of Management Education, vol. 1: Challenges Facing Business Schools around the World (pp. 277-293). London: Palgrave Macmillan UK.

Duriau, V.J., Reger, R.K. \& Pfarrer, M.D. (2007). A content analysis of the content analysis literature in organization studies: Research themes, data sources, and methodological refinements. Organizational Research Methods, 10(1), $5-34$.

Dutton, J.E., Roberts, L.M. \& Bednar, J. (2010). Pathways for positive identity construction at work: Four types of positive identity and the building of social resources. Academy of Management Review, 35(2), 265-293.

Engwall, L. (2004). The Americanization of Nordic management education. Journal of Management Inquiry, 13(2), 109-117.

Eurostat (2016). Total Intramural R\&D Expenditure (GERD) by Sectors of Performance, http://appsso.eurostat.ec.europa.eu/nui/show.do?dataset=rd_e_gerdtot\&lang=en (accessed: 1st Dec 2018).

Gelman, A. (2015). Editorial commentary: The connection between varying treatment effects and the crisis of unreplicable research: A Bayesian perspective. Journal of Management, 41(2), 632-643.

Gelman, A. \& Loken, E. (2014). The statistical crisis in science. American Scientist, 102(6), 460-465.

George, G. (2012). From the editors: Publishing in AMJ for non-U.S. authors. Academy of Management Journal, 55(5), 1023-1026.

Green, S.E. Jr., Yuan, L.I. \& Nohria, N. (2009). Suspended in self-spun webs of significance: A rhetorical model of institutionalization and institutionally embedded agency. Academy of Management Journal, 52(1), 11-36.

Greenwood, R. \& Suddaby, R. (2006). Institutional entrepreneurship in mature fields: The big five accounting firms. Academy of Management Journal, 49(1), 27-48.

Grey, C. (2010). Organizing studies: Publications, politics and polemic. Organization Studies, 31(6), 677-694. 
Habib Bajwa, N.U., König, C.J. \& Harrison, O.S.V. (2016). Toward evidence-based writing advice: Using applied linguistics to understand reviewers' expectations. Academy of Management Learning \& Education, 15(3), 419-434.

Hambrick, D.C. (2007). The field of management's devotion to theory: Too much of a good thing? Academy of Management Journal, 50(6), 1346-1352.

Hensel, P.G. (2017). Legitymizacja badań organizacji. Warszawa: PWN.

Hensel, P.G. (2019). Supporting replication research in management journals: Qualitative analysis of editorials published between 1970 and 2015. European Management Journal, 37(1), 45-57.

Hillman, A.J. \& Rynes, S.L. (2007). The future of double-blind review in management. Journal of Management Studies, 44(4), 622-627.

Horn, S. (2017). Non-English nativeness as stigma in academic settings. Academy of Management Learning \& Education, 16(4), 579-602.

Jia, L., You, S. \& Du, Y. (2012). Chinese context and theoretical contributions to management and organization research: A three-decade review. Management and Organization Review, 8(1), 173-209.

Juusola, K., Kettunen, K. \& Alajoutsijärvi, K. (2015). Accelerating the Americanization of management education. Journal of Management Inquiry, 24(4), 347-369.

Kieser, A. (2004). The Americanization of academic management education in Germany. Journal of Management Inquiry, 13(2), 90-97.

Kipping, M., Usdiken, B. \& Puig, N. (2004). Imitation, tension, and hybridization: Multiple "Americanizations" of management education in Mediterranean Europe. Journal of Management Inquiry, 13(2), 98-108.

Koźminski, A.K. (2008). Anatomy of systemic change polish management in transition. Communist and Post-communist Studies, 41, 263-280.

Kwiatkowski, S. \& Koźmiński, A.K. (1992). Paradoxical country - management education in Poland. The Journal of Management Development, 11(5), 28-33.

Lok, J. (2010). Institutional logics as identity projects. Academy of Management Journal, 53(6), 1305-1335.

Mangematin, V. \& Baden-Fuller, C. (2008). Global contests in the production of business knowledge: Regional centres and individual business schools. Long Range Planning, 41(1), 117-139.

March, J.G. (2005). Parochialism in the evolution of a research community: The case of organization studies. Management \& Organization Review, 1(1), 5-22.

March, J.G. (2007). The study of organizations and organizing since 1945. Organization Studies, 28(1), 9-19.

Obłój, K. (2008). Kierunki reformy nauki polskiej. Przeglad Organizacji, 5, 3-4.

Podsakoff, P.M. et al. (2008). Scholarly influence in the field of management: A bibliometric analysis of the determinants of University and author 
impact in the management literature in the past quarter century. Journal of Management, 34(4), 641-720.

Saunders, J., Wong, V. \& Saunders, C. (2011). The research evaluation and globalization of business research. British Journal of Management, 22(3), 401-419.

Schroter, S. et al. (2008). What errors do peer reviewers detect, and does training improve their ability to detect them? Journal of the Royal Society of Medicine, 101(10), 507-514.

Scott, W.R. (2008). Institutions and Organizations. Ideas and Interests (3. ed.). Los Angeles: SAGE Publications.

Simsek, Z., Heavey, C. \& Jansen, J.J.P. (2013). Journal impact as a diffusion process: A conceptualization and the case of the journal of management studies. Journal of Management Studies, 50(8), 1374-1407.

Suddaby, R. \& Greenwood, R. (2005). Rhetorical strategies of legitimacy. Administrative Science Quarterly, 50(1), 35-67.

Sveningsson, S. \& Alvesson, M. (2003). Managing managerial identities: Organizational fragmentation, discourse and identity struggle. Human Relations, 56(10), 1163-1193.

Śliwa, M. \& Johansson, M. (2014). How non-native English-speaking staff are evaluated in linguistically diverse organizations: A sociolinguistic perspective. Journal of International Business Studies, 45(9), 1133-1151.

Śliwa, M. \& Johansson, M. (2015). Playing in the academic field: Non-native English-speaking academics in UK business schools. Culture and Organization, 21(1), 78-95.

Tiratsoo, N. (2004). The "Americanization" of management education in Britain. Journal of Management Inquiry, 13(2), 118-126.

Tolbert, P.S. \& Zucker, L.G. (1996). The institutionalization of institutional theory. In: S.R. Clegg, C. Hardy \& W. Nord (eds.). The Handbook of Organization Studies (pp. 175-190). Thousand Oaks (CA): SAGE.

Tsui, A.S. (2013). The spirit of science and socially responsible scholarship. Management \& Organization Review, 9(3), 375-394.

Üsdiken, B. (2010). Between contending perspectives and logics: Organizational studies in Europe. Organization Studies, 31(6), 715-735.

Vogel, R. (2012). The visible colleges of management and organization studies: A bibliometric analysis of academic journals. Organization Studies, 33(8), 1015-1043.

Zilber, T.B. (2015). Turning a disadvantage into a resource: Working at the periphery. European Management Journal, 33(6), 423-430. 